Memoria conducente al título de periodista de la Universidad de Chile

Profesor guía: Hans Mülchi

"Neltume '81"

Evelyn Campos, Cristian Fuentes y Andrea Sánchez

\title{
La tierra sangrante
}

\section{Reseña de Claudia Lagos Lira}

"Esta tierra está regada con sangre”

Pedro Cardyn, "Doc"

A fines de los 70, el Movimiento de Izquierda Revolucionaria (MIR) puso en marcha la llamada "Operación Retorno", que consideró el ingreso clandestino a Chile de sus militantes para rearticular al Movimiento en el país, organizar la lucha armada contra la dictadura, en general, y la guerrilla rural, en particular. Uno de los episodios de esa historia -que tuvo ribetes dramáticos- fue la guerrilla de Neltume, en la región de La Araucanía.

La historia narrada por sus propios protagonistas Guerrilla en Neltume: una historia de lucha y resistencia en el sur chileno (2003, LOM Ediciones) - es desoladora: un grupo de disciplinados militantes ingresan a Chile de forma clandestina y se internan en la cordillera de Neltume, con el fin de organizar la lucha armada. La apuesta tenía como supuesto que los campesinos y habitantes de la zona serían -naturalmente- proclives a apoyar la apuesta del MIR y contribuir con su grano de arena a derrocar a la dictadura.

Sin embargo, el proceso no tiene buen aspecto desde un principio: dos de sus miembros son detenidos $-\mathrm{y}$ desaparecidos hasta hoy-intentando ingresar por la frontera desde Argentina. El pueblo chileno no era -como ellos esperaban - un apoyo seguro para sus propósitos. De hecho, en 1981, atemorizados por los militares y conminados a denunciar a cualquier extraño, son los mismos aldeanos quienes los delatan en dos oportunidades, lo que deriva en dos emboscadas en la cordillera. El contingente 
se desparrama, sin víveres, con escasas posibilidades de sobrevivencia, desarmados y sin medicamentos ni pertrechos. Varios mueren en la primera emboscada. Otros tantos, en la segunda. Algunos de los sobrevivientes, incluso, son ejecutados por agentes de inteligencia en Concepción (1984).

Neltume 81, el documental de Campos, Fuentes y Sánchez es el primer registro documental de esta historia poco conocida de la lucha contra la dictadura, lo que es su primer acierto: regresar al sitio del suceso, con algunos de sus sobrevivientes y protagonistas (familiares), en un intento por reconstruir lo que pasó arriba en la cordillera (en una cita al documental Estadio Nacional, de Carmen Luz Parot).

Lo primero que corresponde destacar en la obra de Campos, Fuentes y Sánchez es el excelente trabajo de producción. El trabajo de archivo (imágenes fijas y en movimiento), es también notable (archivos personales, prensa, imágenes de archivo de prensa y otros).

El esfuerzo de producción en lo que se refiere a rodaje es otro punto alto de la propuesta: locaciones, sobrevivientes, familiares, responsables políticos (Pascal Allende) y, en general, una paleta diversa de fuentes (vivas y documentales) son una fortaleza del trabajo que acá evaluamos. La apuesta por recorrer y reconstruir los hechos con los protagonistas, en los mismos lugares donde ocurrieron, es otro acierto tanto de la narración y de contenidos como de la producción.

La investigación cumple con los requisitos para las memorias de título de la carrera de periodismo del ICEI: es un trabajo grupal, original, de carácter periodístico, donde el equipo integra conceptos, métodos, habilidades y teorías adquiridas en la formación de pregrado y los aplica en un tema profesional. El trabajo de Campos, Fuentes y Sánchez es original, inédito en el ámbito de lo audiovisual y bien reporteado.

En una segunda parte, en lo que se refiere a las observaciones del trabajo propiamente audiovisual, hay una debilidad que me parece relevante para efectos de la construcción del relato: los autores se dirigen a un espectador más o menos enterado de los acontecimientos que constituyeron el intento de guerrilla en Neltume. Al 
prescindir de una voz en off que narre y entregue información adicional y de contexto o, bien, de otras estrategias que permitan cubrir los vacíos que las fuentes no necesariamente abordan, el documental da por supuesto ciertos hechos. Si bien es una apuesta estética, a nuestro entender, el resultado no cumple totalmente con la necesidad de contar la historia y, por lo tanto, deja vacíos.

En esa misma línea, la construcción del relato tiene algunos problemas de orden lógico: el documental se inicia con imágenes del entorno natural de Neltume (un protagonista por sí mismo de la historia) y luego sigue con el Che y el proyecto político del MIR; pasa luego por las imágenes del Golpe de Estado del 11 de septiembre de 1973, para continuar con la Operación Retorno. En ese pasaje de la historia, se da un salto temporal al pasado, recordando la experiencia del Complejo Maderero Panguipulli y su historia de organización política, para después volver a la romería como acción de recuperación de memoria y continuar con la Operación Retorno, para volver al Golpe y a la detención de militantes, sus condenas y posteriores extrañamientos y exilio. Desde ahí, organizan el regreso en la clandestinidad.

A nuestro entender, el hilo conductor -tal como hemos descrito- es errático, sobre todo en la primera mitad del documental (hasta antes de la primera emboscada). O, en otras palabras, podemos afirmar que a partir de los relatos limpios de los protagonistas (sin voz en off ni otras huellas que guíen la visión del documental), no alcanza para explicar y entender en detalle y con especificidad la sucesión de los hechos y la participación específica de cada uno de sus protagonistas. Hay "huellas" que los autores no utilizan para indicar al espectador información relevante (como cuáles y de quiénes son las imágenes de archivo, como por ejemplo, las imágenes posteriores a la emboscada, de la CNI o momentos específicos como la romería, que uno desprende de la lectura del informe).

Del mismo modo, y dado la renuncia de los autores a recurrir a estas "huellas" que marquen el relato (una voz en off, carteles, GC, entre otros), hay información que es importante y que el documental no especifica: ¿cuántos conformaban exactamente el destacamento que se interna en la cordillera? 
¿Cuándo llegan? ¿Quiénes primero y quiénes después? ¿Cuánto tiempo estuvieron en la cordillera? ¿Cómo se salvan los sobrevivientes? En esta misma línea, la información que contiene el informe que acompaña el documental y que se refiere a las historias personales de los protagonistas no se ve reflejada en este, lo que es, a nuestro entender, una pérdida, ya que conocer cómo se integran al movimiento y sus historias personales da cuenta de mucho mejor manera -que como es narrado al inicio del documental- del proyecto político del MIR.

Aún así, el documental Neltume 81 es un aporte a la historia política reciente de Chile, a la formación de periodistas y al campo audiovisual nacional en general. No hay que perder de vista que se trata de un trabajo de título y que tiene todo por crecer. 